\title{
Attitude Towards Acceptability Of The Girl Child In Families Belonging To Upper And Lower Socio-Economic Class
}

\author{
Muhammad Athar Hussain \\ Department of Education \\ The Islamia University of Bahawalpur \\ Imtiaz Ahmad \\ Department of Teacher Education \\ University of Karachi \\ Amber Qadar \\ Department of Management Sciences \\ The Islamia University of Bahawalpur
}

\begin{abstract}
The present study was an attempt made to determine the discrimination as practised against the girl child and as expressed through the attitudes of girl children themselves and their parents. In order to test the hypotheses, an A x B factorial design (A denoting subjects and B socioeconomic status) with each variable at two levels: girls and mothers, and upper and lower class areas, respectively and 50 replicates in each cell $(\mathrm{N}=200)$, was employed to study the differences on the main effects and their interaction. One hundred girls ranging from seven to 13 years of age and those having brothers were selected along with their mothers. Their responses were obtained on the two Attitude Scales (one meant for the girl child and the other for the parent) having fairly high test-retest reliability and criterion-related validity. These responses were verified by an interview of the subjects taken later on. The attitude scores of subjects, computed as per standard procedure, were subjected to statistical tests to determine differences in discrimination. The results showed the F-ratio calculated for the main effect 'girls and their mothers' and 'upper and lower class' to be highly significant.
\end{abstract}

Keywords: Acceptance, Attitude, Girl Child, Socio-Economic Status, Families.

$$
\begin{aligned}
& \text { تخاخيص }
\end{aligned}
$$

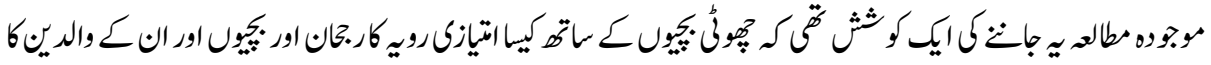

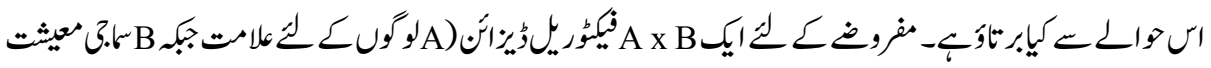

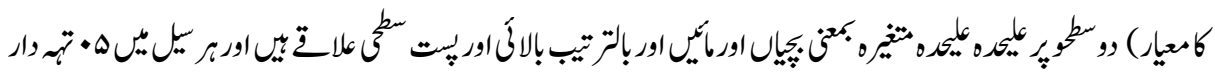

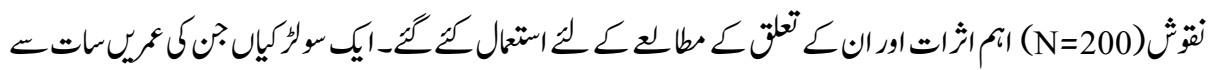




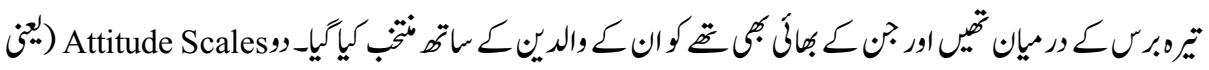

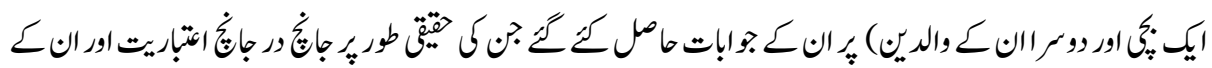

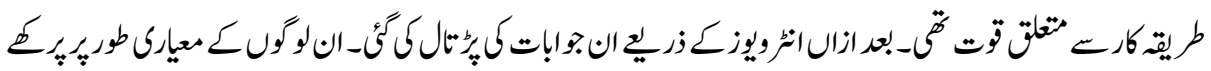

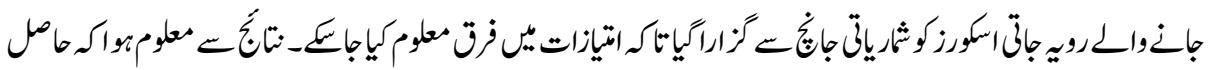

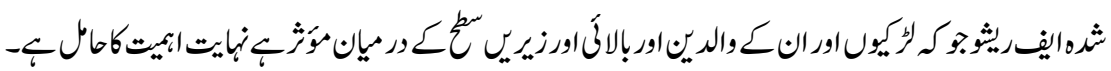

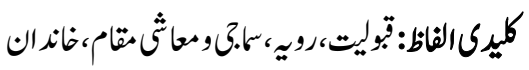

\section{Introduction}

\section{Perception Regarding the Birth of a Girl Child}

Most of the underdeveloped and developing countries nurture bias against females. To reorient the social attitude and government policies, the year 1990 was declared the 'Year of Girl Child' for the SAARC countries indicating that the girl children in these countries faced problems in addition to the problems faced by children in general. The year 1990 for the Girl Child was followed by the SAARC decade (Ghosh, 1990).

The problems of girls in Pakistan and other SAARC countries are not only the problems of the privations of poverty and general issues associated with conditions in the developing countries, but they refer to situations rising from their being girls (Munir \& Neman, 2013). The Pakistani society, despite being divided on the basis of baradari ${ }^{1}$, wealth and region, universally regards the birth of the girl child as unwelcome. On the contrary, the birth of a male child is celebrated with sweets, music and gaiety. $\mathrm{He}$ is looked upon as a saviour on whom the parents will be able to lean in their old age, the one who will perform their last rites and carry the family through ages (Ashiq, Azeem, Shazia \& Azra, 2011).

The girl child faces many odds in her struggle for survival, caught in a maze of cultural practices and prejudices that strip her of individuality and mould her into a submissive, self-sacrificing daughter and then a mother. Her labour as an important contributor to the family income either as a domestic worker, an agricultural hand, or a caretaker for her

\footnotetext{
${ }^{1}$ Baradari means 'Brotherhood' originating from the Persian word برادر Baradar meaning "Brother". In Pakistan it is used to denote a number of social strata.
} 
younger siblings, robs her not only of her childhood, but also her innocence, making her ignorant and weak in the process (Ambreen \& Mohyuddin, 2013).

Shabbir et al. (2003) indicated that "the girl child's perception of herself and her role is conditioned by her early socialization, a process which eventually moulds her into the stereotyped prisoner of her gender." They further explained the situation as:

"At each and every step of life, the girl follows her mother. She sees her mother working through sickness and pain and suffering ill health without complaining. She also sees her mother subsisting on leftovers and she learns to do the same. Told to talk, softly and dress modestly, the girl child gradually acquires the qualities of submissiveness, meekness and selfsacrifice which allow her to accept the domination of male oriented values. Whatever she acquires from her family and especially from mother, she tries to transmit all this to her daughter (p. 306)."

The root of the problem of discriminatory treatment being meted out to girls lies in the status of women in society and their expected roles. Girls are socialized into docility, blind obedience and total dependence. This situation prevalent at home is reinforced by the society. Socializing the girls from their childhood to accept their status and the ideology of male supremacy assures continuance of the discriminatory treatment.

Afzal (2000) interviewed girl child parents for the child-rearing practices and the parental attitudes towards the observed children. A significant discrimination was found in the parental attitudes towards the girl child. The parents genuinely believed that girls should not be treated the same way as boys, and they have to be trained for their difficult adult role as wives and mothers. Some common explanations given for the differential treatment were that the sons carry the family name that one can stay with them in old age and that girls are the other's property.

A somewhat similar study was conducted by Rafiq (2000) on 200 respondents. It revealed that the mother's child - rearing practices overall as well as in three aspects: independence, motivation and social mobilization, as perceived by girl children, were significantly poorer than boy children. But no significant differences were found between the perceptions of the child -rearing practices of rural and urban children.

A few studies are ' related with the different child-rearing practices for the boys and girls. Mumtaz and Shaheed (1987) point out that there is differential socialization of girls and boys with greater emphasis on achievement, competence, independence and assumption of responsibilities in sons and in interpersonal relations in daughters. Rukshanda (2005) reported that fathers encouraged boys in mathematics and girls in interpersonal skills. Chaudhary, Chani and Pervaiz (2012) also observed that boys are encouraged in risk- 
taking, freedom, independence and are left unsupervised in younger ages; while girls are encouraged for cultural conformity and dependency. Akhter (2011) observed that family, society and culture play a major role in socialization and development of sex roles.

Studies mentioned above indicate that the girls in the Indian society face discrimination in their early childhood as well as later life. Obviously, there is still a long way to go before both society and parents accept that girls have the equal rights to those of boys.

It is therefore true that, in Pakistan, the family structure and values function in such a way that the daughters grow up looking upon themselves as inferior and subservient, entitled to much less of everything than sons: less opportunity, less authority, less property, low status, less power and virtually no choices.

Dwelling on the problem of bias towards the girl child, the present study was undertaken to determine the discrimination- against the girl child as expressed through attitudes of girl children themselves and their parents (Aware Girls, Young Feminists Movement \& Mamacash, 2014).

Attitudes being the ways by which people organize and categorize their information and feelings on various matters, an attempt was made to gauge the attitudes of girls and their parents regarding the rearing of girls versus boys. In other words, it was sought to determine the social status of girls especially as prevailing at home.

By means of conducting the present study as a public opinion survey, the investigator sought to indirectly create public awareness towards the rights of the girl children. Of course, highlighting the attitudes towards the girl child amounted to implicitly changing the negative or discriminatory attitudes towards her as prevalent in household and society at large.

\section{Methodology}

\section{Problem and Hypotheses}

As the study entailed approaching the girl children to determine what they think about themselves in view of their parents' attitude towards them, an impressionable age-group of female children was selected in order to get genuine and honest responses. Similarly, to lend authenticity to responses, efforts were made to study the attitudes of parents towards their female children vis-a-vis male children. Also, as the discrimination and bias may be found to be more in lower class than upper class due to the lower social awareness of residents and general environmental conditions, the sample was taken from both the socio-economic statuses to present a realistic picture. Care was taken to 
generalize the data by including families engaged in different occupations and those having different economic status.

The present research was conducted under the following two hypotheses:

1. Girl would report more discrimination against the girl child than what their parents would report.

2. Girls and their parents from the lower socioeconomic status would report more discrimination against the girl child than those from the upper class families.

\section{Design}

An AXB factorial design, A (Subjects) denoting the two levels of girls and their parents and $\mathrm{B}(\mathrm{SES})$ denoting the two groups, with 50 replicates in each cell $(\mathrm{N}=200)$, was employed to determine the differences on the main effects and their interaction. The design in the tabular form is given below:

\begin{tabular}{|c|c|c|c|}
\hline & A (S & jects) & \\
\hline & Girls & Parents & \\
\hline $\begin{array}{c}\text { B } \\
\text { Socioeconomic }\end{array}$ & $\begin{array}{c}\mathbf{A}_{1} \mathbf{B}_{1} \\
\text { Girls Belong to } \\
\text { Upper Class = 50 }\end{array}$ & $\begin{array}{c}\mathbf{A}_{2} \mathbf{B}_{1} \\
\text { Parents Belong to } \\
\text { Upper Class }=50\end{array}$ & Upper Class \\
\hline Status & $\begin{array}{c}\mathbf{A}_{1} \mathbf{B}_{2} \\
\text { Girls Belong to } \\
\text { Lower Class }=\mathbf{5 0}\end{array}$ & $\begin{array}{c}\mathrm{A}_{2} \mathrm{~B}_{2} \\
\text { Parents Belong to } \\
\text { Lower Class }=\mathbf{5 0}\end{array}$ & Lower Class \\
\hline
\end{tabular}

\section{Sample}

One hundred girls ranging from seven to 13 years of age and those having brothers were randomly selected as subjects in equal number from both the lower as well as upper SES groups. In addition to girls, their parents (mostly mothers) were also approached for their responses. As originally planned, the study also envisaged the interview of fathers of girls for ascertaining their attitudes towards the girl child, but they, being preoccupied with jobs or business, could hardly be contacted during day time. Despite this, the investigator did succeed in contacting and obtaining responses from twelve fathers (ten from upper class and two from lower class) on holidays. However, this sample, being insufficient, was not taken into account in the present study and responses only from mothers were considered. 
As the study required genuine responses to a sensitive issue, female children falling within the age-group of seven to thirteen years were chosen as subjects. The said age group seemed to have an advantage of excluding children below the age of seven years who could not properly express their attitudes as well as those above the age of thirteen years who could project their feelings in a distorted manner. In view of the delicate agegroup chosen, an affectionate rapport was established with the young subjects that were further strengthened by the offer/provision of incentives in some cases.

Subject to the basic requirement of girls having brothers, care was taken to ensure random selection of subjects by means of covering all lanes or mohallas of town and also including a sufficient number of slum areas in the sample. Care was also taken to study families engaged in different occupations. The sample of parents also constituted working and non-working mothers.

\section{Apparatuses}

Two Attitudes Scales, one for girls and the other for their parents, each scale consisting of five statements of questions were used in order to obtain attitudinal responses of girls and their mothers who endorsed ( ) the statements in terms of ' Yes 'or 'No' or certain choice responses.

The selected statements or questions represented real life situations. An attempt was made to include in the scales almost every major aspect of child-rearing in respect of which discrimination and bias between the male and female children could be reported. Such aspects as household work, nutrition, sharing love and affection, educating children, fulfilling their needs and desires, and belief in old customs and traditions in general were sought to be studied.

After selecting the statements, they, were given to four judges for evaluating whether the same could obtain appropriate responses from subjects. The judges generally belonged to the fields of psychology and education. A graduate housewife and a working lady also judged the statements. The modifications as suggested by judges were incorporated, as far as possible, in the finalized format.

The selected statements were tried out in the case of six or seven children who, along with their mothers, responded to the issues raised therein. The questionnaire approach was supplemented by the interview of respondents so as to get reliable information. After having verified the practicability of the selected items, the final data were gathered.

In the case of both the Attitude scales, the test-retest reliability was determined. A part of the total sample i.e. 25 girls and their mothers, drawn from upper class $(\mathrm{N}=15)$ and lower 
class $(\mathrm{N}=10)$ areas was tested and retested on the different scales after a period of approximately three months. The reliability correlation coefficients were found to be 0.95 in the case of girls and 0.90 in the case of mothers, both significant beyond the .01 level.

The criterion-related validity of the Attitude Scales was also determined. For this purpose, opinions about subjects relating to the original statements constituting the two Attitude Scales were sought from the 25 peers (16 from upper class and nine from lower class), one peer for each of the 25 girl children and their mothers. These peers were those persons who kept in close contact with the respective subjects. They constituted family members, friends and neighbourers of the subjects. Using the original scoring system for their answers, their scores were correlated with those of the subjects and product moment correlation was computed between the two sets of scores. The criterion-related validity coefficient of correlation was found to be 0.78 in the case of girls and 0.54 in the case of mothers, both significant beyond the .01 level.

\section{Procedure}

The subjects were approached individually and their responses were obtained after establishing rapport with them and clarifying their doubts, if any. In addition to specific answers, details of their views were sought from them.

After having obtained the responses; the same were scored. In the case of girls, their responses which reflected no discrimination against the girl child or even favoured her over the brother, were each given a score of three (3), the responses that reflected an equal favour for the girl and her brother, were given a score of two (2), and the responses which reflected the discrimination against the girl child and favour for the brother, were given a score of one (1). In the case of parents, their responses reflecting discrimination against the girl child were given a score of (1) and those showing no discrimination were given a score of three (3). The scoring system was so devised as to maintain the uniformity between the scores of girls and their parents' responses. Thus, the maximum score and the minimum score could be fifteen (15) and five (5), respectively, in both the cases.

Following further the criterion of uniformity, the ranges of scores for the responses of the girl children and their parents were determined as follows:

\section{Table: 1}

Range of scores for the responses of the girl children

\begin{tabular}{|c|c|c|}
\hline Discriminated & Moderately discriminated & Not discriminated \\
\hline $1-5$ & $6-10$ & $11-15$ \\
\hline
\end{tabular}


Table: 2

Range of scores for the responses of the parents

\begin{tabular}{|c|c|}
\hline Discriminated & Not discriminated \\
\hline $1-5$ & $11-15$ \\
\hline
\end{tabular}

The 'moderate' category devised for the girl children implicitly corresponded to the moderate category in the case of the parents as it contained scores from 6 to 10 .

Using the aforesaid scoring systems, scores of upper class and lower class, and simultaneously mothers were determined (for upper class girls, $\mathrm{M}=8.28$, S.D. $=7.63$; for lower class girls, $\mathrm{M}=7.6, \mathrm{SD}=11.65$. For upper class mothers, $\mathrm{M}=14.08, \mathrm{~S} . \mathrm{N})$. 2.23; and for lower class mothers, $\mathrm{M}=10.88$, S.D. $=10.67$ ).

\section{Findings and Discussion}

The present study intended to determine the attitudes towards the girl child, employed the analysis of variance technique to determine the differences and the interaction between the main effects (Subjects and SES). The results are shown below:

Table: 3

Summary of ANOVA

\begin{tabular}{|c|c|c|c|c|c|c|}
\hline S \# & $\begin{array}{c}\text { Source of } \\
\text { Variance }\end{array}$ & $\begin{array}{c}\text { Sum of } \\
\text { Squares }\end{array}$ & df & $\begin{array}{c}\text { Mean } \\
\text { Square }\end{array}$ & F & p \\
\hline 1 & $\begin{array}{c}\text { A } \\
\text { (Subjects) }\end{array}$ & 1030.58 & 1 & 1030.58 & 252.16 & $<.01$ \\
\hline 2 & $\begin{array}{c}\text { B } \\
\text { (Socioeconomic } \\
\text { Class) }\end{array}$ & 188.18 & 1 & 188.18 & 46.04 & $<.01$ \\
\hline 3 & $\begin{array}{c}\text { A X B } \\
\text { Subjects X } \\
\text { SES) }\end{array}$ & 79.38 & 1 & 79.38 & 19.42 & $<.01$ \\
\hline 4 & $\begin{array}{c}\text { Error: } \\
\text { Within } \\
\text { treatment }\end{array}$ & 801.04 & 196 & 4.09 & & \\
\hline 5 & Total & 2099.18 & 199 & & & \\
\hline
\end{tabular}

Table 3 reveals that the $\mathrm{F}$ ratios obtained for the main effects of $\mathrm{A}$ (Subjects) and $\mathrm{B}$ (SES) are highly significant (for $A, F=252.16$, $d f=1 / 196, p<.01$; for $B, F=46.04$, $d f=.1 / 196$, $\mathrm{p}<.01)$. The interaction between the main effects was also found to be highly significantly (for A X B, F = 19.42, df =1/196, p<.01). 
The results explain that there is a clear-cut difference between the attitudes of girls and their mothers. The girls reported more discrimination against themselves as practiced by their mothers than did their mothers. The lower mean attitude score for the both SES groups' girls combined i.e. 7.94 than that for the mothers i.e. 12.48 also shows that the girls expressed significantly more discrimination toward themselves than did their mothers. These results are in line with the first hypothesis stated earlier.

Shahid et al. (2013) in their study noticed discrimination in the parental attitudes toward the daughters. The parents genuinely believed that girls should not be treated the same way as boys as the sons carry the family name, one can stay with the son in old age, whereas the girls are the other's property. In the present study, majority of the parents belongs to the upper as well as the lower socioeconomic classes were also found to believe the same when they were individually interviewed.

The $\mathrm{F}$ ratio for the main effect $\mathrm{B}$ i.e. the sample belongs to the both upper and lower SES was also found to be significant beyond the .01 level. This explains that the urban Ss (girls and their mothers) differed in terms of discrimination scores from the rural Ss. The mean score of the upper class sample (girls and mothers) was found to be 11.8 and the mean score for the lower class sample was 9.24. This again indicates that the discrimination in the upper SES was much less in comparison to discrimination in the lower SES where it was reported to a greater extent by both the girls and their mothers. The significant difference confirms the second hypothesis as mentioned earlier. These results are supported by the study by Shahid et al. (2013) and Singh \& Prabhakar (1991) who reported that there were significant differences in the attitude towards the girl child between the upper and lower class subjects.

The interaction between the $\mathrm{A}$ and $\mathrm{B}$ main effects was found to be significant. This implies an interdependent relationship between the subjects and the areas. In other words, it means that the difference between the responses of $\mathrm{A}_{1}$ (girls) and those of $\mathrm{A}_{2}$ (mothers) is not independent of the levels of the effect $\mathrm{B}$ i.e. upper and lower socioeconomic statuses.

Apart from the main effects being analyzed by analysis of variance, individual responses were also analyzed by means of chi-square analyses. These analyses merely indicated differences and, at best, supplemented, in part, the results already obtained through the analysis of variance. The results are given in Table 4 . 
Table: 4

Chi-square analyses for frequencies of responses of girl children and their mothers

\begin{tabular}{|c|c|c|c|c|c|c|c|}
\hline \multirow{3}{*}{$\begin{array}{l}\text { S } \\
\#\end{array}$} & & om upper an & ower socio-ec & nomic statuse & & & \\
\hline & \multirow[t]{2}{*}{ Subjects } & \multicolumn{3}{|c|}{ Response Categories } & \multirow[t]{2}{*}{$\mathbf{X}^{2}$} & \multirow[t]{2}{*}{ df } & \multirow[t]{2}{*}{$\mathbf{p}$} \\
\hline & & Discriminated & $\begin{array}{c}\text { Moderately } \\
\text { Discriminated }\end{array}$ & $\begin{array}{c}\text { Not } \\
\text { Discriminated }\end{array}$ & & & \\
\hline \multirow[t]{2}{*}{1.} & $\begin{array}{l}\text { Girls } \\
(\mathrm{N}=100)\end{array}$ & 5 & 82 & 13 & \multirow[t]{2}{*}{85.38} & \multirow[t]{2}{*}{2} & \multirow[t]{2}{*}{$<.01$} \\
\hline & $\begin{array}{l}\text { Mothers } \\
(\mathrm{N}=100)\end{array}$ & 2 & 20 & 78 & & & \\
\hline \multirow[t]{2}{*}{2.} & $\begin{array}{l}\text { Upper Class } \\
\text { Girls }(\mathrm{N}=50)\end{array}$ & 5 & 36 & 9 & \multirow[t]{2}{*}{8.14} & \multirow[t]{2}{*}{2} & \multirow[t]{2}{*}{$<.02$} \\
\hline & $\begin{array}{l}\text { Lower Class } \\
\text { Girls }(\mathrm{N}=50)\end{array}$ & 0 & 46 & 4 & & & \\
\hline \multirow[t]{2}{*}{3.} & $\begin{array}{l}\text { Upper Class } \\
\text { Mothers } \\
(\mathrm{N}=50)\end{array}$ & 0 & 1 & 49 & \multirow[t]{2}{*}{23.32} & \multirow[t]{2}{*}{2} & \multirow[t]{2}{*}{$<.01$} \\
\hline & $\begin{array}{l}\text { Lower Class } \\
\text { Mothers } \\
(\mathrm{N}=50)\end{array}$ & 2 & 19 & 29 & & & \\
\hline \multirow[t]{2}{*}{4.} & $\begin{array}{l}\text { Upper Class } \\
\text { Girls }(\mathrm{N}=50)\end{array}$ & 5 & 36 & 9 & \multirow[t]{2}{*}{65.59} & \multirow[t]{2}{*}{2} & \multirow[t]{2}{*}{$<.01$} \\
\hline & $\begin{array}{l}\text { Upper Class } \\
\text { Mothers } \\
(\mathrm{N}=50)\end{array}$ & 0 & 1 & 49 & & & \\
\hline \multirow[t]{2}{*}{5.} & $\begin{array}{l}\text { Lower Class } \\
\text { Girls }(\mathrm{N}=50)\end{array}$ & 0 & 46 & 4 & \multirow[t]{2}{*}{32.16} & \multirow[t]{2}{*}{2} & \multirow[t]{2}{*}{$<.01$} \\
\hline & $\begin{array}{l}\text { Lower Class } \\
\text { Mothers } \\
(\mathrm{N}=50)\end{array}$ & 2 & 19 & 29 & & & \\
\hline
\end{tabular}

To begin with, a small part of the girl children's sample i.e. five Ss reported that they were discriminated whereas only two mothers reported such discrimination. A larger portion of the sample of girl children $(\mathrm{N}=82)$ reported that they were moderately discriminated by their parents. They felt discriminated due to different childrearing practices adopted for them by their parents, especially mothers, who were evidently more generous towards their sons rather than daughters. On the other hand, only 20 mothers reported that they had a moderate discriminatory attitude towards their daughters and were more inclined to their sons.

It may be noted that the discriminatory attitude towards the girl child still exists whether it is the upper class or the lower socioeconomic class, although the parents of the girls from both the SESs mostly deny this. But on the basis of the reports of the girls children 
it can be said so as out of the total 100 girls children, 87 reported themselves to be discriminated against (five reported discrimination and 82 moderate discrimination). The chi-square analysis for this comparison was found to be significant beyond the .01 level. This lends some support to the first hypothesis.

This finding resembles, in part, the one obtained by Rai (1991) who studied the childrearing practices of mothers as perceived by boys and girls. It was found that the girl child was less acceptable to the mother in comparison to the male child as per childrearing practices.

When scores of the upper and lower class girls (Table 4) were compared, it was found that five upper class girls reported that they were discriminated whereas no lower class girl so reported. The reason for that may be that, in the present study, all lower class girl children (except one) were found to be getting education. Education being a criterion of non-discrimination, no lower class girl could be said to be discriminated against. The one girl belong to this group who was not studying was herself not willing to study, as was found when she was personally interviewed. She was not compelled by her parents to stay at home. In the upper class area also, all the girl children were found to be getting education when they were individually assessed. However, discrimination against them was found in respect of birthday celebration. It was found that, mostly their sons' birthday was celebrated more enthusiastically by their parents. Majority of the girls also reported that they were not allowed to remain cut of their homes for a long period. They could not go to the market alone, especially at odd hours.

Out of the 50 lower class girls, 46 reported moderate discrimination towards themselves. Although a sizable sample of upper class girls i.e. 36 also felt the same, yet their number is less than that of the lower class sample. The results explain that the people are still caught in the web of socio-cultural traditions and customs. It is more evident in the lower class families than in the upper class families. They consider girls as a burden and sons as the caretakers of their old age. A small part of the upper class (9) and the lower class (4) sample of girls reported that they were not discriminated. They were cared for, attended to and loved by their parents as were their brothers. A few girls even reported during interview that they were better cared for and loved by their parents as compared to brothers. In view of the total, girls' responses indicating moderate discrimination, it can be pointed out that the lower class girls are more discriminated against than the upper class girls. The significant value $(\mathrm{p}<.02)$ partly confirms the second hypothesis mentioned earlier.

The samples of the mothers of both upper and lower socioeconomic class were also compared. It was found that no upper class mother reported that she discriminated against her daughter and only two lower class mothers agreed to be discriminatory. Only one 
upper class mother accepted that she discriminated moderately against her daughter; whereas 19 lower class mothers accepted the game. On the other hand, the larger portion of the upper class sample i.e. 49 mothers completely denied the fact that they ever discriminated against their daughters whereas 29 lower class mothers did so. Statistically, a significant chi-square strongly confirms the second hypothesis. The upper class mothers did not express their discriminatory attitude against their daughters perhaps due to their sophistication in maintaining double standards. The acceptance of discrimination by the lower class mothers may be due to their innocence. In any case, they did not attach much importance to the issue of discrimination between the boy and the girl child due to their belief in the old traditions.

In a comparison made between the responses of the upper class girls and their mothers, five girls reported that they were discriminated against, but no mother reported so. Out of the 50 upper class girls, 36 expressed that their parents did have clear-cut preferences for their brothers and they were at least moderately discriminated against. However, with the exception of one mother, 49 mothers denied any discrimination at all. Nine girls also reported that they were not discriminated against. This analysis was also found to be significant at the .01 level which again confirms the first hypothesis in part.

A somewhat different result was obtained when the scores of the lower class girls and their mothers were compared. Surprisingly, no girl reported that she was discriminated, whereas two mothers reported such discrimination. Upon interviewing the girls, it was found that both of them belonged to very poor families and had four to five sisters but only one brother. So, their parents considered them as a burden on the family and favoured their only sons. The girls apparently did not report out of inhibition. Forty-six lower class girls reported themselves as being moderately discriminated against whereas only 19 mothers accepted this. Twenty nine mothers disagreed that they ever discriminated against their daughters and four girl children also reported that they were not discriminated. However, on the whole, the results bear out the second hypothesis, the chi-square being significant at the .01 level.

\section{Conclusions}

The investigator found that the girl children did get discriminated against in their families, more so in the lower class setting. It goes without saying that an integrated and holistic approach to the girl child's development is essential for the creation of a new environment in which she can be valued and nurtured. The search for new and bold efforts to give the girl child her due, to allow her to evolve to her full potential involves a process of social mobilization that will make her everyone's concern. Every effort should be made to remove the disparities under which the girl child is born and grows up if she is to be taken out of the maze of neglect in which she has been lost for centuries. 


\section{References}

Afzal, A. (2000). The Attitude of Mothers towards the Education of their Daughters in Changer Community. Research Report, Deptt. of Rural Sociology, Univ. of Agri., Faisalabad, Pakistan.

Akhter, N. (2011). Push and Pull Factors Behind Domestic Violence Practices in Bahawalpur, Pakistan. Journal of Educational Research, vol.14:1, pp.154-163.

Ambreen, Mamonah \& Mohyuddin, Anwaar (2013). Gender Biased and Parental Attitudes towards Education: A Case Study of Village Dasuha, District Faisalabad. Academic Research International, vol.4:1, pp.140-147.

Ashiq, Hussain Dogar; Azeem, Muhammad; Shazia, Feroze \& Azra, Shakoor (2011). Parents' Gender Biased Attitude towards Education. International Journal of Humanities and Social Science, vol.1:16, pp.296-304.

Aware Girls and Young Feminists Movement in Collaboration with Mamacash (February- 2014). Survey on the Perceptions and Attitudes of People Towards Domestic Abuse in Pakistan.

Ghosh, Shanti (1990). Girl Child in the SAARC Countries: Current Issues in Child Health - II. Indian Journal of Pediatr, vol.57, pp.15-19.

Munir, Syed Ahmad \& Neman, Mohammad (2013). Mothers, Daughters and Education: Exploring the Role and Relationship between Culture and Socio-Economic Factors. PUTAJ: Humanities and Social Sciences, vol.20, pp.201-220.

Naimatullah Hashmi, Muhammad Iqbal Zafar \& Munir Ahmad (2008). Cultural Determinants of Female Educational Attainment in Rural Jhang, Punjab, Pakistan. Pakistan Journal of Agriculture Science, vol.45:1.

Rai, G.C. (1991). A Study of the Acceptability of Girl Child in Terms of Child Rearing Practices. UGC Sponsored National Seminar on Psychological Aspects in the Social Acceptability of Girl Child, Kurukshetra.

Shabbir Hussain, Muhammad Zakaria, Yousuf Hassan, Yousaf Mukhtar \& Sadiq Ali (2003). Parents Attitude towards the Education of Their Daughters: A Case Study of Faisalabad-Pakistan. International Journal of Agriculture \& Biology, vol.5:3, pp.306-307. 
Shahid, Iqbal et al. (2013). Traditional Attitude of Parents and its Impact on Female Educational Attainment in Rural Hafizabad, Pakistan. World Applied Sciences Journal, vol.27:1, pp.87-91.

Singh, A. \& Prabhakar, I. (1991). Social Acceptability of the Girl Child - An Analytical Study. UGC Sponsored National Seminar on Psychological Aspects in the Social Acceptability of Girl Child, Kurukshetra.

Dr. Muhammad Athar Hussain is Lecturer in the Department of Education, The Islamia University of Bahawalpur, Bahawalpur.

Dr. Imtiaz Ahmad is an Assistant Professor in the Department of Teacher Education, University of Karachi.

Amber Qadar is Lecturer in the Department of Management Sciences, The Islamia University of Bahawalpur, Bahawalpur. 